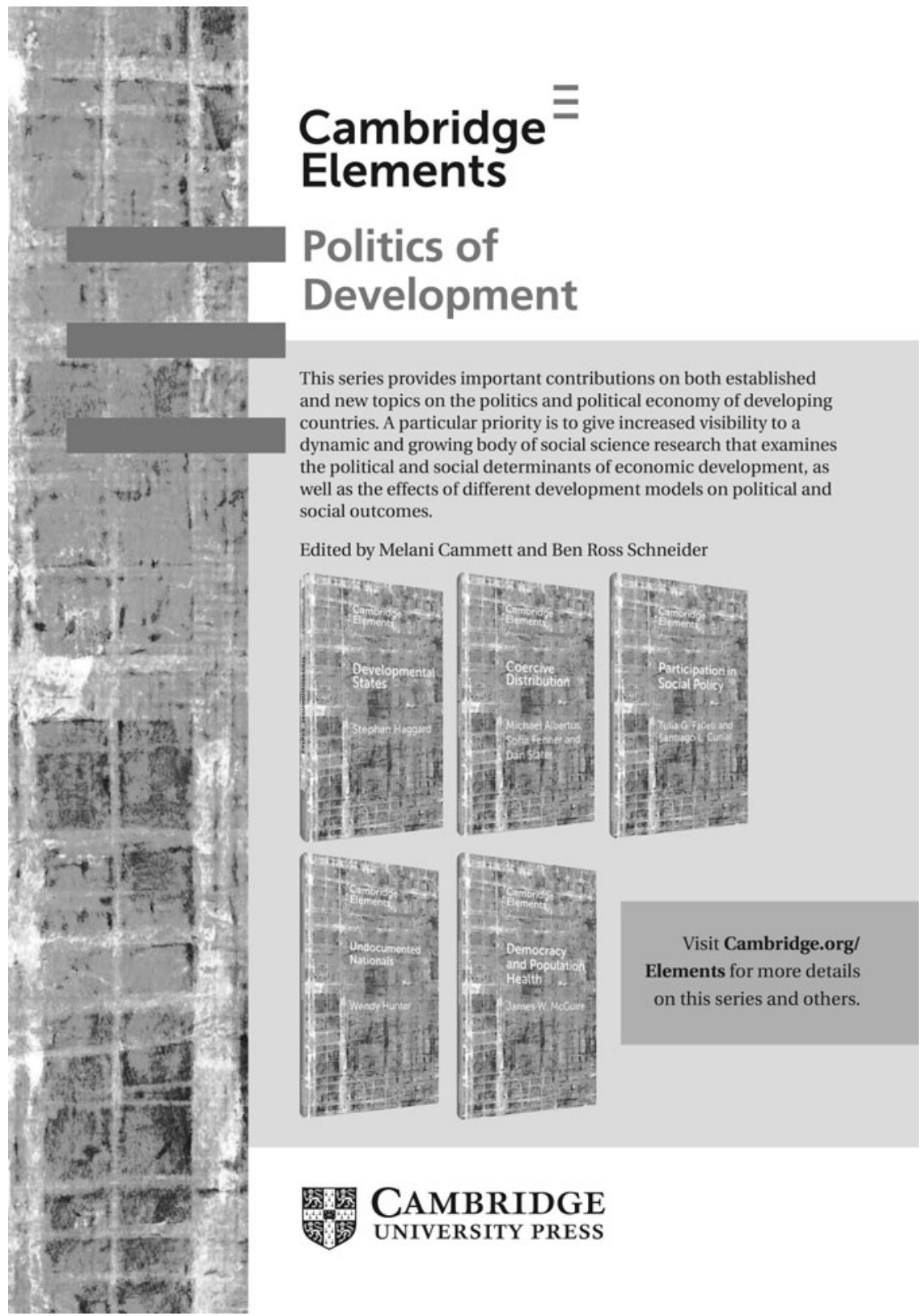




\section{WHAT CAPITALISM}

NEEDS

Forgotten Lessons

of Great Economists

John L. Campbell and John A. Hall

There is no inevitable logic of capitalism. Capitalism's stability depends on how well nation-states manage it and on social cohesion.

"Inspired by the insights of six key economists, Campbell and Hall offer a masterful interpretation of the global political economy from the early 20 th-century until today. What political and economic conditions enabled the golden era of prosperity after the trauma of the Second World War? Why did this period end as economic inequality combined with slower

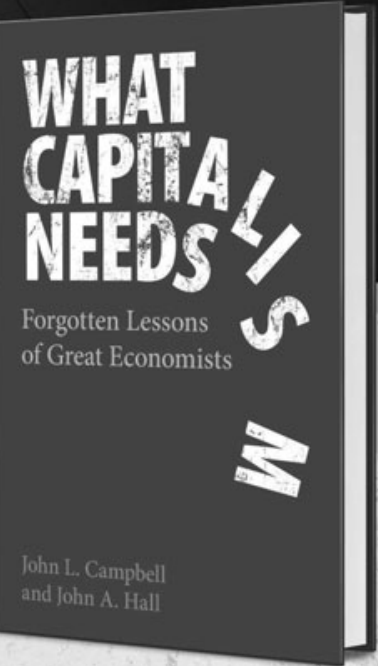
growth, greater instability and resurgent intolerance? And what lies ahead, as China assumes a leading role in the world's economy? In a compelling and carefully researched analysis, the authors identify the critical conditions upon which the viability of global capitalism depends and map out ways to meet the challenges of the future." Bruce $G$. Carruthers, Northwestern University

"This superb book reminds us of one enduring insight. Economists like Smith, Hirschman, List, Keynes, Schumpeter and Polanyi understood what modern economics has forgotten. Capitalism does not flourish when markets are fully free. It thrives when they are socially embedded and politically well governed. A turbulent 20 th century has made this pandemic moment ripe for this timeless reminder." Peter J. Katzenstein, Cornell University

"A capitalist economy is never pure capitalism. Its operation is, as John Campbell and John Hall show us so clearly and effectively, both supported and impeded by an array of institutions and government policies, and it produces consequences that themselves affect the economy's functioning." Lane Kenworthy, University of California, San Diego

9781108487825 | Hardback | f20 | \$24.95 | September 2021 


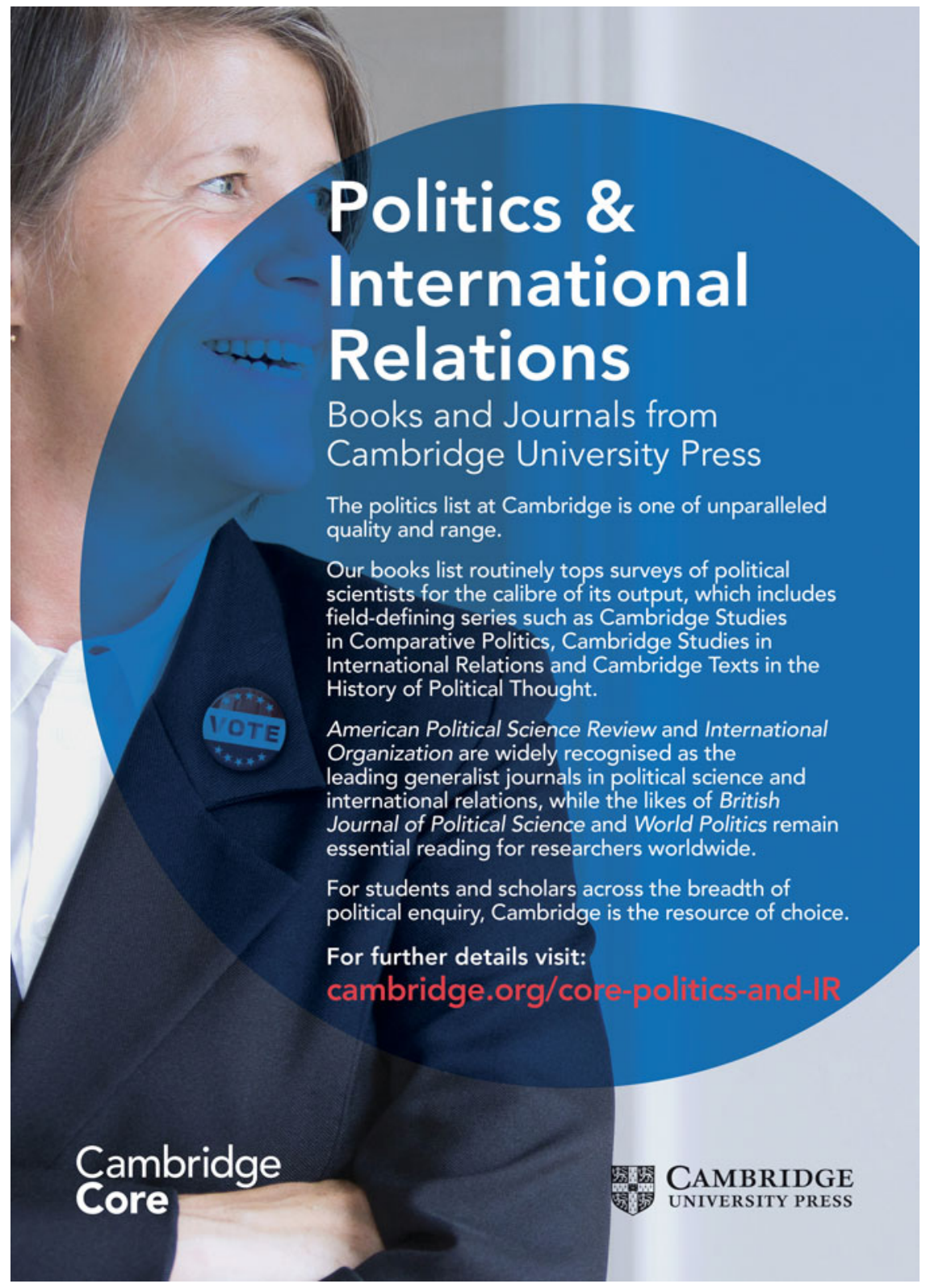




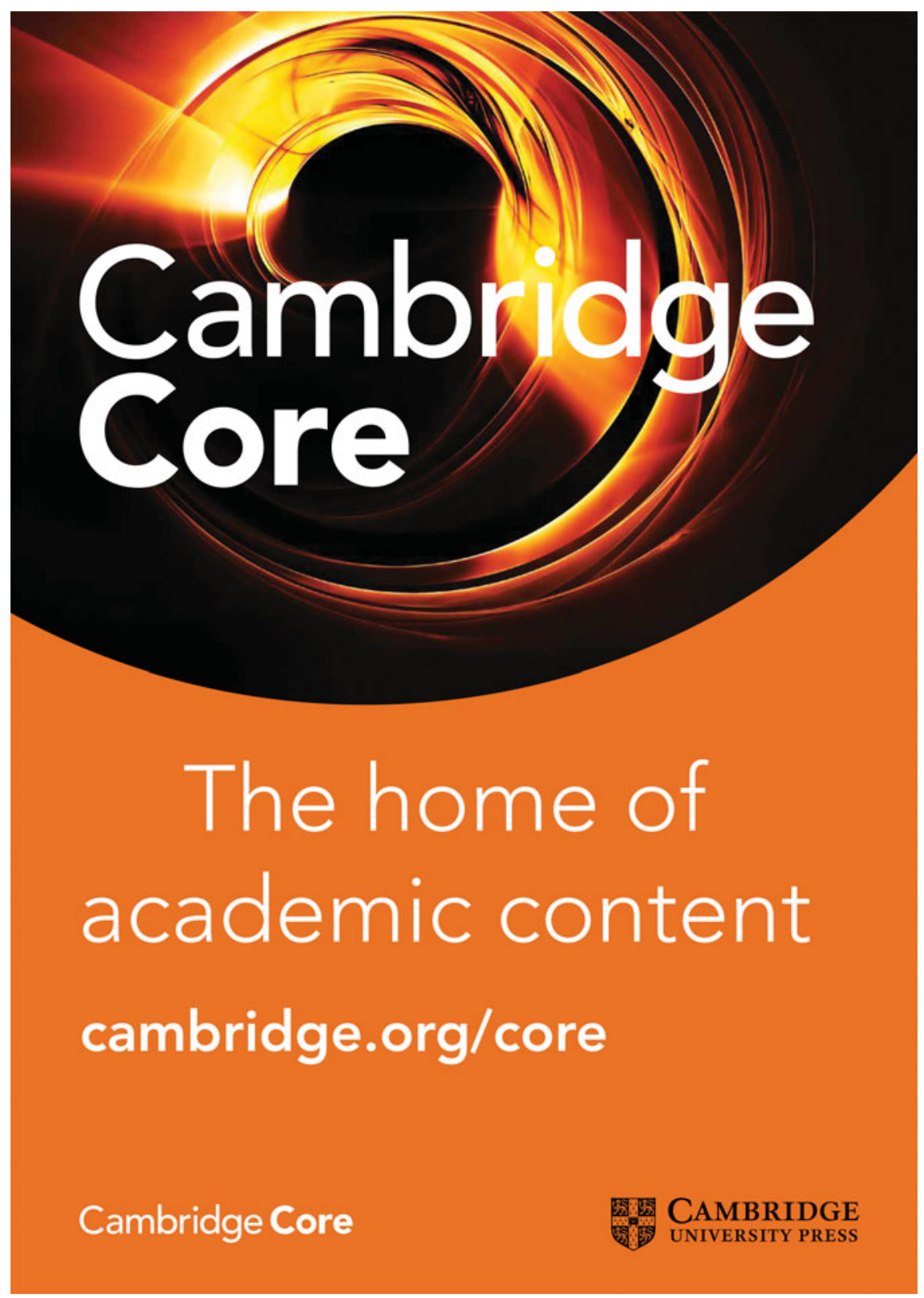




\section{The Review of Politics INSTRUCTIONS TO CONTRIBUTORS}

\begin{abstract}
AIMS AND SCOPE. The Review of Politics publishes primarily philosophical and historical studies of politics, especially those concentrating on political theory and American political thought. The journal also includes thoughtful scholarly reflections on all aspects of politics-including analysis of institutions and techniques, international relations, comparative politics, literary reflections on politics or political interpretations of literary works, constitutional theory and practices.
\end{abstract}

\section{MANUSCRIPT SUBMISSION AND}

REVIEW. To submit a manuscript for consideration please send an electronic file (formatted in MS Word):

\section{THE REVIEW OF POLITICS ONLINE SUBMISSION}

http://mc.manuscriptcentral.com/cup/rop

Complete instructions are provided on the website. The menu will prompt the author to provide all necessary information, including the manuscript category, contact information for the corresponding author (phone number, fax number, email address), and suggested reviewers. The website will automatically acknowledge receipt of the manuscript and provide a reference number. The Editor will assign the manuscript to anonymous reviewers and every effort will be made to provide the author with a review in a timely fashion.

Authors uncomfortable with online submission may send their manuscript as an email attachment to rop.editor.1@nd.edu:

Editor, The Review of Politics

University of Notre Dame

2005 Jenkins Nonovic Halls

Notre Dame, IN 46556-7000

574-631-6623

ROP.Editor.1@nd.edu

reviewofpolitics.nd.edu

BOOK REVIEWS. All correspondence regarding book reviews should be sent to our editorial offices at Rop.Editor.1@nd.edu.

MANUSCRIPT LENGTH. Normal length of published manuscripts is $8,000-11,000$ words . The entire manuscript, including notes and quotations, should be double-spaced.
Author anonymity. Because manuscripts are evaluated anonymously they should not bear the author's name or institutional affiliation. Please remove all references or acknowledgments that might indicate the identity of the author.

Abstract and keywords. All article submissions should include an abstract of 100-150 words.

\section{MANUSCRIPT PREPARATION AND \\ STYLE. The Review of Politics follows the Chicago Manual of Style for standards of citation, punctuation, and other editorial considerations.}

Figures and tables. Appendices, tables, and figures should be numbered consecutively throughout the article and be included on separate pages appearing after the reference section. Each figure must be submitted electronically as a separate file. Electronic versions should submitted as $1200 \mathrm{dpi}$ TIFF or EPS files at $100 \%$ of a suitable final size. Charts, graphs, or other artwork should be professionally rendered and computer generated.

\section{COPYEDITING AND PAGE PROOFS.}

The publisher reserves the right to copyedit and proofread all articles accepted for publication. Page proofs of an article will be sent to the lead author of an article for correction of typographical errors only; authors must notify the publisher or the editorial office of any changes within 72 hours of receipt of proof or approval will be assumed.

\section{COPYRIGHT TRANSFER AGREEMENT.} Papers with multiple authors are reviewed with the assumption that all authors concur with its submission. A Copyright Transfer Agreement, with certain specified rights reserved by the author, must be signed and returned to the Editor by senior authors of accepted manuscripts, prior to publication. The Review of Politics does not accept manuscripts for review that are under review elsewhere, previously published, or already committed for publication. 
BOOKS REVIEWED

Lucy Cane, Sheldon Wolin and Democracy: Seeing through Loss

Davina Cooper, Feeling Like a State: Desire, Denial, and the Recasting of Authority

George Crowder, The Problem of Value Pluralism: Isaiah Berlin and Beyond

Pierre Manent, Montaigne: Life without Law

Joel Alden Schlosser, Herodotus in the Anthropocene

... and more

Thornton Lockwood, "Aristotle's Politics on Greeks and Non-Greeks"

John P. McCormick, "Aristocratic Insolenzia and the Role of Senates in Machiavelli's Mixed Republic"

Lee Ward, “Trust and Distributive Justice in John Locke's Politics of Money"

Ryan P. Hanley, "Distance Learning: Political Education in the Persian Letters"

Lisa Herzog, "“Old Facts, New Beginnings: Thinking with Arendt about Algorithmic Decision-Making"

\section{Cambridge Core}

For further information about this journal please go to the journal website at: cambridge.org/rop 